\title{
DEVELOPMENT AND VALIDATION OF A FAST AND SIMPLE RP-HPLC METHOD FOR THE DETERMINATION OF DIOSMIN AND HESPERIDIN IN COMBINED TABLET DOSAGE FORM
}

\author{
Marjan Piponski, Tanja Bakovska Stoimenova, Marina Topkoska, Stefan Stefov, \\ Magdalena Piponska, Gordana Trendovska Serafimovska \\ Quality Control Department, Replek Farm Ltd., Kozle 188, 1000 Skopje, Republic of Macedonia \\ piponski@yahoo.com
}

\begin{abstract}
A fast, simple, accurate and robust reversed phase HPLC method for the simultaneous determination of two flavonoids, hesperidin and diosmin, in combined tablets was developed and validated. This method uses a short $\mathrm{C} 8$ column with dimensions of $75 \mathrm{~mm} \times 4 \mathrm{~mm}$ with $5 \mu \mathrm{m}$ particles thermostated at $30{ }^{\circ} \mathrm{C}$, and a mobile phase composed of formic acid $(\mathrm{pH} 4.1$ and $0.05 \%, V / V)$ and methanol $(58: 42, V / V)$, delivered at a flow rate of $1.2 \mathrm{ml} / \mathrm{min}$, with UV detector signal monitoring at $280 \mathrm{~nm}$ and an injection volume of $5 \mu$ l. These chromatographic conditions yielded chromatograms with symmetric peaks of hesperidin, eluting at a $\sim 2$ min retention time, and diosmin, at a $\sim 4.5$ min retention time, with a total run time cycle of $6 \mathrm{~min}$. The method validation parameters confirmed excellent values for accuracy, linearity and reproducibility. This method is suitable for routine analysis in pharmaceutical and food quality control laboratories.
\end{abstract}

Keywords: diosmin; hesperidin; tablets; HPLC-UV; method

\section{РАЗВОЈ И ВАЛИДАЦИЈА НА БРЗ И ЕДНОСТАВЕН RP-HРLC-MЕТОД ЗА ОДРЕДУВАЫЕ НА ДИОСМИН И ХЕСПЕРИДИН ВО КОМБИНИРАНИ ТАБЛЕТНИ ДОЗИ}

Развиен и валидиран е брз, едноставен, точен и робусен реверзно-фазен HPLC-метод за симултано одредување на два флавоноида, хесперидин и диосмин, во комбинирани таблети. Методот користи кратка колона С8 со димензии $75 \mathrm{~mm} \times 4 \mathrm{~mm}$ со честички од $5 \mu \mathrm{m}$, која е термостатирана на $30{ }^{\circ} \mathrm{C}$, и мобилна фаза составена од мравја киселина $(\mathrm{pH} 4,1$ и $0,05 \%, V / V)$ и метанол $(58: 42, V / V)$, која се пропушта низ колоната со проток $1,2 \mathrm{ml} / \mathrm{min}$, со мониторирање на сигналот со УВ-детектор на $280 \mathrm{~nm}$ и инјекционен волумен од $5 \mu 1$. Овие хроматографски услови резултираа со хроматограми со симетрични пикови на хесперидин, кој елуира со време на ретенција од 2 минути, и диосмин, со време на ретенција од $\sim 4,5$ минути, со вкупна должина на циклусот на анализа од 6 минути. Валидационите параметри на методот потврдија одлични вредности за точност, линеарност и репродуцибилност. Методот е многу подобен за рутински анализи во фармацевтски лаборатории и во лаборатории за контрола на квалитетот на храна.

Клучни зборови: диосмин; хесперидин; таблети; HPLC-UV; метод

\section{INTRODUCTION}

Diosmin and hesperidin are molecules that belong to a group of organic compounds known as flavonoids. Flavonoids are a large group of plant pigments sharing the same basic chemical struc- ture, i.e. a three-ringed molecule with hydroxyl (OH groups) attached (Fig. 1).

Diosmin $\left(\mathrm{C}_{28} \mathrm{H}_{32} \mathrm{O}_{15}\right)$ (Fig. 1a) is a naturally occurring flavonoid glycoside that can be isolated from various plant sources or derived from the flavonoid hesperidin. It was first isolated in 1925 
from Scrophularia nodosa, and first introduced as a therapeutic agent in 1969. Diosmin is considered to be a vascular-protecting agent used to treat chronic venous insufficiency, hemorrhoids, lymphedema and varicose veins. As a flavonoid, diosmin also exhibits anti-inflammatory, freeradical scavenging and antimutagenic properties. It differs molecularly from hesperidin by the presence of a double bond between the carbon atoms in the central carbon ring (Fig. 1). Diosmin can be manufactured by extracting hesperidin from citrus rinds, followed by the conversion of hesperidin to diosmin. Diosmin has been used for more than 30 years as a phlebotonic and vascular-protecting agent, and has recently begun to be investigated for other therapeutic purposes, including cancer, premenstrual syndrome, colitis and diabetes [1].

Hesperidin $\left(\mathrm{C}_{28} \mathrm{H}_{34} \mathrm{O}_{15}\right)$ (Fig. 1b) is the predominant flavonoid in citrus fruits, primarily in sweet orange and lemon, and consequently in juices made of these citruses [2].

This combination of flavonoid drugs has been used to manage the symptoms of chronic venous disease, including edema of the lower limbs, for many years [3].

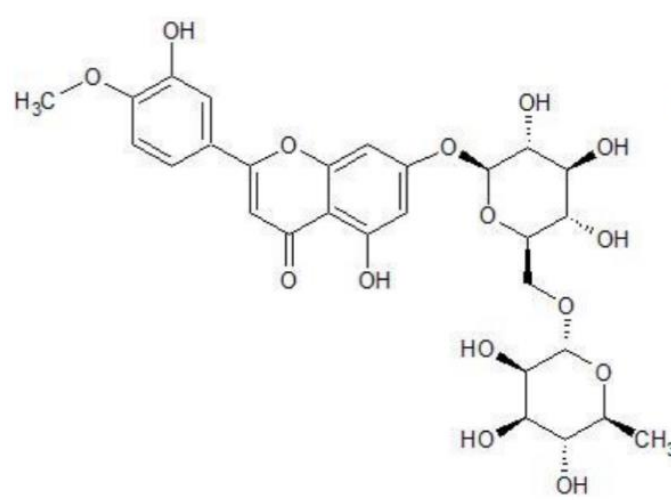

a) Diosmin

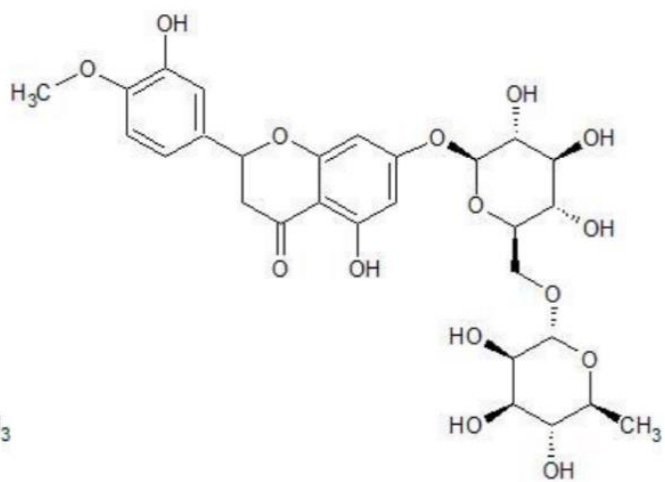

b) Hesperidin

Fig. 1. Structural formulas of a) diosmin and b) hesperidin

There are many published chemical analytical methods for the simultaneous determination and quantification of these compounds in food products and solid pharmaceutical dosage forms. Srilatha et al. [4] described a UV spectrophotometric method for the simultaneous determination of diosmin and hesperidin in pharmaceutical preparations. Moldovan et al. [5] published a spectrophotometric method for diosmin determination only, based on the reaction of diosmin with 4aminoantipyrine in the presence of hexacyanoferrate (III) in an alkaline medium and the subsequent formation of a purple colored product with $\lambda_{\max }$ at $524.5 \mathrm{~nm}$. Dalia and Shereen [6] created a fluorimetric method for the simultaneous determination of diosmin and hesperidin, involving the formation of a ternary complex with a terbium cation $\left(\mathrm{Tb}^{3+}\right)$ in the presence of Tris buffer. Although they possess simplicity and applicability, and achieve the stated accuracy and precision, these bunch, summary, UV spectrophotometric analytical methods for the determination of more components in one sample are not commonly used in pharmaceuticalchemical analysis. Chromatographic methods are almost indispensible for such multicomponent analysis, because previous separation of the components of multicomponent samples is preferred, before their quantification, in order to achieve as high as possible accuracy.

El-Shafae and El-Domiaty [7] published LC methods for the determination of diosmin and hesperidin in plant extracts and pharmaceutical formulations using a non-endcapped LiChrosorb RP-18 column and methanol-water mobile phase, which is impractical for the stabilization of peak shapes and retention times of molecules, like flavonoids. Kanaze et al. [8] described RP-HPLC separation of diosmin, hesperidin and naringin using a C8 RP column and ternary eluent mixture containing toxic and expensive tetrahydrofuran in combination with acetic acid and water. The fifth edition of the $\mathrm{Eu}-$ ropean Pharmacopoeia [9], published in 2004, included a method for diosmin determination using a highly efficient $3-\mu \mathrm{m} \mathrm{C18}$ column. Šatinský et al. [10] published a method for the determination of four flavonoids, rutin, troxerutin, diosmin and hesperidin, in food supplements by implementing fused-core column technology, i.e. using a more 
sophisticated fused-core column, Ascentis RPAmide $(100 \mathrm{~mm} \times 3.0 \mathrm{~mm}, 2.7 \mu \mathrm{m})$, and mobile phase composed of acetonitrile and a water solution of acetic acid with $\mathrm{pH} 3$ at a temperature of 50 ${ }^{\circ} \mathrm{C}$. A highly efficient Waters Symmetry C18 column $(100 \mathrm{~mm} \times 4.6 \mathrm{~mm}, 2.6 \mu \mathrm{m})$ in combination with methanol and $0.1 \%$ o-phosphoric acid as a mobile phase was proposed for assay testing of diosmin and hesperidin in combined tablet dosage form by Mishra et al. [11]. A stability indicating RP-HPLC method for the determination of diosmin and hesperidin in combination, developed by Anwer et al. [12] using UV signal monitoring at 346 $\mathrm{nm}$ and methanol/water mobile phase, yielded notably asymmetrical peak shapes of diosmin and hesperidin. A distinct chromatographic method was published in 2015 by Patel et al. [13] using a quality by design approach for the simultaneous estimation of hesperidin methyl chalcone, hesperidin and ascorbic acid in combined dosage form, with a mobile phase containing phosphate buffer at $\mathrm{pH}$ 4.2, methanol, triethylamine and acetonitrile, and a C18 Kromasil column $(250 \mathrm{~mm} \times 4.6 \mathrm{~mm}, 5$ $\mu \mathrm{m})$. Ibrahim et al. [14] published a method for the quantification of four vasoactive phytochemicals, diosmin, hesperidin, rutin and ascorbic acid, in pharmaceutical preparations with a Phenomenex C18 column $(250 \mathrm{~mm} \times 4.6 \mathrm{~mm}, 5 \mu \mathrm{m})$ and elution using acetonitrile and a phosphate buffer $(\mathrm{pH} 4.0$ and $50 \mathrm{mM}$ ). Szymański et al. [15] developed a method for the simultaneous determination of diosmin and hesperidin in pharmaceuticals by RPLC using a C18 column and a methanol/water mobile phase with added ionic didecyldimethylammonium lactate as a mobile phase modifier, for shortening the analysis time and achieving better symmetry of the resulting chromatographic peaks.

We also consulted the literature on flavonoid isocratic chromatographic separations and working with target analytes other than diosmin and hesperidin, with the aim of finding new mobile phase concepts. Kuntić et al. [16] used a binary mobile phase composed of methanol and water acidified to pH 2.8 with phosphoric acid (50:50, V/V). Biesaga et al. [17] reported a slightly more acidic mobile phase composed of a phosphate buffer ( $\mathrm{pH} 2.2$ and $50 \mathrm{mM})$ and acetonitrile $(75: 25, \mathrm{~V} / \mathrm{V})$. Yam et al. [18] published a method with a ternary concept of mobile phase composed of $\mathrm{NaH}_{2} \mathrm{PO}_{4}(\mathrm{pH} 3.5$ and $20 \mathrm{mM}$ ), acetonitrile and iso-propanol (45:30:15, $V / V)$. Islam et al. [19] reported a chromatographic method with formic acid $(0.1 \%, V / V)$ and acetonitrile $(70: 30, V / V)$.

\section{AIM}

After summarizing all previously published methods, our aim was to create a fast, simple and efficient chromatographic method with less toxic organic solvent consumption and that avoids phosphate buffering salts, which will use cheaper short RP columns with $5-\mu \mathrm{m}$ particles. Such a method enables less demanding and faster equilibration and yields shorter run times with symmetric peak shapes of diosmin and hesperidin, efficiently separated for accurate determination. Additionally, the developed method should be very applicable for frequent high-throughput analysis in different industrial or other types of quality control laboratories.

\section{MATERIALS AND METHODS}

The chromatographic analyses were performed on an automated Varian PDA Pro-Star system controlled by software Galaxie version 1.91, an UHPLC Dionex Ultimate 3000 controlled by Chromeleon software and a Shimadzu Nexera XR controlled by Lab Solutions software. The HPLC column used, a LiChrospher RP Select B $75 \mathrm{~mm} \times$ $4 \mathrm{~mm}, 5 \mu \mathrm{m}$, and the suitable pre-column with dimensions of $4 \mathrm{~mm} \times 4 \mathrm{~mm}$, filled with an identical matrix as the used column, were purchased from Merck, Darmstadt, Germany. Other columns were also tested, including a Purospher C8e STAR 55 $\mathrm{mm} \times 4 \mathrm{~mm}, 5 \mu \mathrm{m}$, a Purospher C8 $125 \mathrm{~mm} \times 4$ $\mathrm{mm}, 5 \mu \mathrm{m}$, a LiChrospher C18 $125 \mathrm{~mm} \times 4 \mathrm{~mm}, 5$ $\mu \mathrm{m}$ (all purchased from Merck, Darmstadt, Germany) and a Discovery C18 $100 \mathrm{~mm} \times 4.6 \mathrm{~mm}, 5$ $\mu \mathrm{m}$ (Supelco Bellefonte, USA). All chemicals used were of EP quality grade. Methanol, formic acid (98-100\%) and ammonia solution $25 \%$ were purchased from Merck, Darmstadt, Germany. Sodium hydroxide was purchased from Sigma-Aldrich, USA. The demineralized water was Stillman produced and had a conductivity less than $1 \mu \mathrm{S}$. Standard substances for diosmin and hesperidin were purchased from Sigma-Aldrich, USA.

Tablets containing a combination of $450 \mathrm{mg}$ of diosmin and $50 \mathrm{mg}$ of hesperidin, the placebo and working standards of diosmin and hesperidin were purchased from Replek Farm Ltd., Skopje, Macedonia.

Test and standard solutions were prepared in a $0.1 \mathrm{M}$ sodium hydroxide solution to final working concentrations of $\sim 0.36 \mathrm{mg}$ diosmin $/ \mathrm{ml}$ and $\sim 0.04 \mathrm{mg}$ hesperidin $/ \mathrm{ml}$. 


\section{RESULTS AND DISCUSSION}

Following our starting concept based on the development of a less toxic, "greener" and cheaper method, methanol was chosen as a mobile phase constituent, in combination with formic acid because of their lower UV cut-off values for achieving better baseline of the chromatograms and because of the better solubility of the analytes. With a $\mathrm{pKa}$ value of $\sim 3.8$, this formate buffer fits much better than an acetate buffer with higher UV cutoff values and a pKa of $\sim 4.8$ [20].

This mobile phase showed to be functional with different types of HPLC columns, i.e. it is not obligatory for the columns used to be endcapped and/or base-deactivated.

Finally, the established and optimized chromatographic conditions are as follows: mobile phase composed of 42 volumes of methanol and 58 volumes of $0.05 \%(V / V)$ formic acid adjusted to $\mathrm{pH} 4.15$ with $10 \%(V / V)$ ammonia solution, HPLC column RP Select B, $75 \mathrm{~mm} \times 4.0 \mathrm{~mm}$ with $5-\mu \mathrm{m}$ particle size, thermostated at $30{ }^{\circ} \mathrm{C}, 1.2 \mathrm{ml} / \mathrm{min}$ mobile phase flow rate, $\mathrm{UV}$ detection at $280 \mathrm{~nm}$ and an injection volume of $5 \mu \mathrm{l}$ (Fig. 2).

The applicability of the mobile phase concept was tested on chromatographic systems and columns with different performances, and the obtained chromatograms are shown in Figs. 3-5.

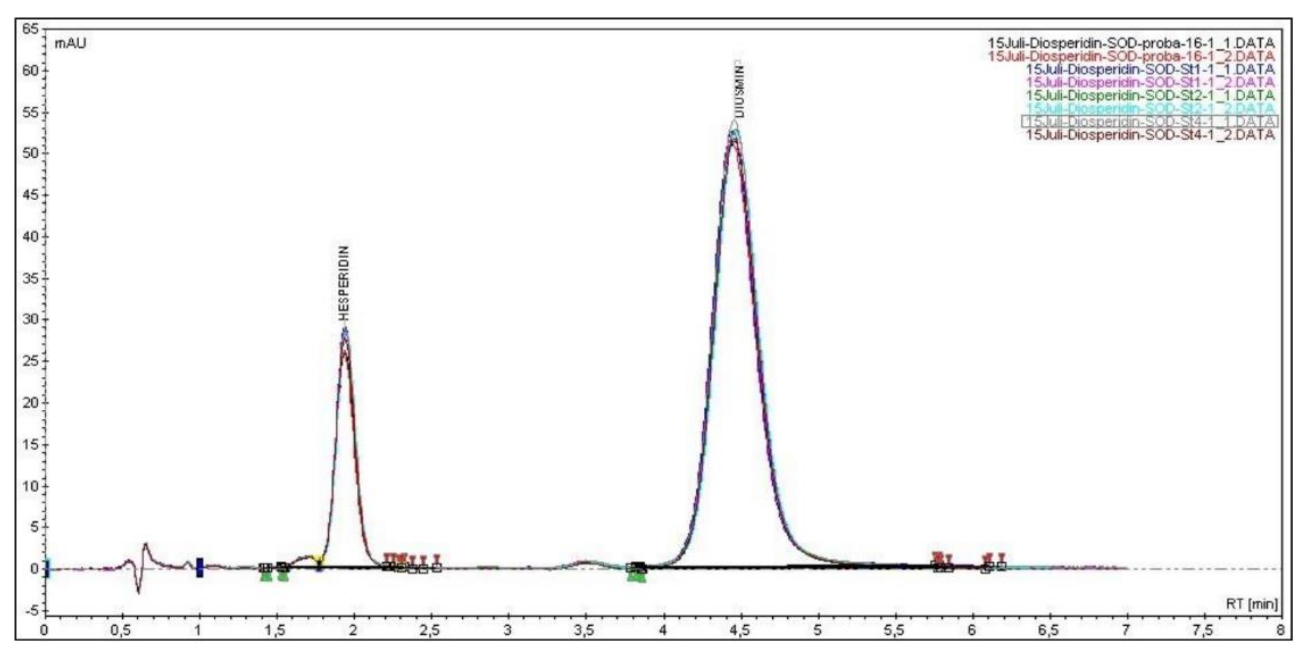

Fig. 2. Chromatograms obtained using final established, optimized and validated chromatographic method, using HPLC Varian

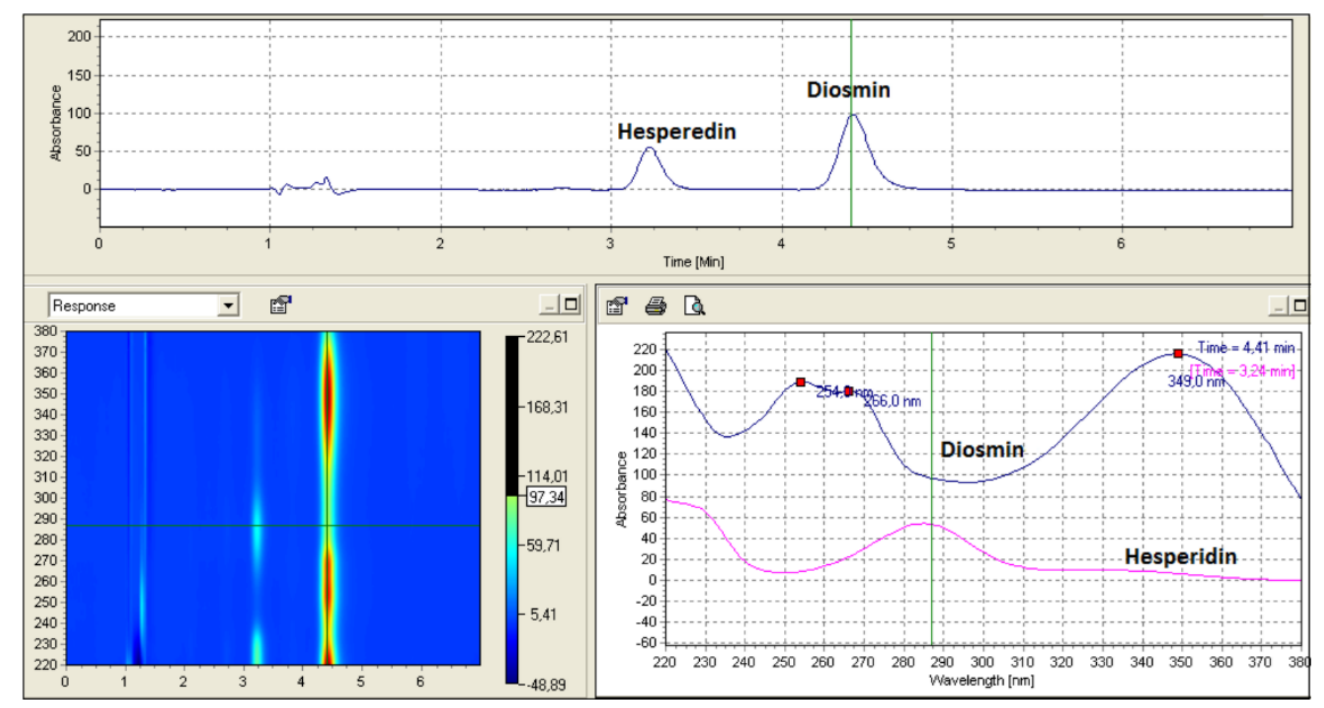

Fig. 3. Chromatogram obtained using HPLC Varian and column Purospher C8 $125 \mathrm{~mm} \times 4 \mathrm{~mm}, 5 \mu \mathrm{m}$, with extracted UV spectra 


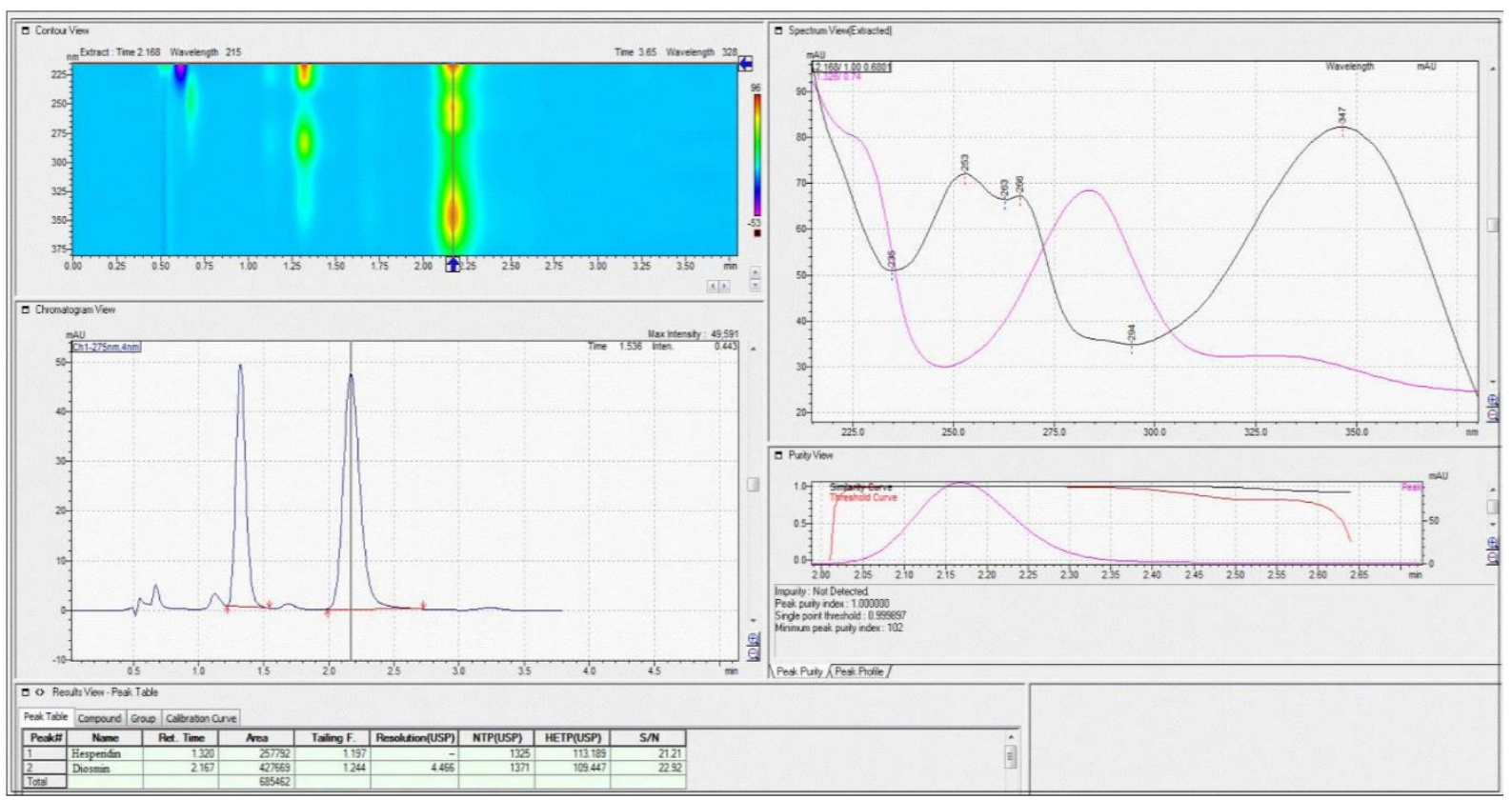

Fig. 4. Chromatogram obtained using UPLC Shimadzu and column Purospher C8 $55 \mathrm{~mm} \times 4 \mathrm{~mm}, 5 \mu \mathrm{m}$, with extracted UV spectra, peak purity and system suitability parameters

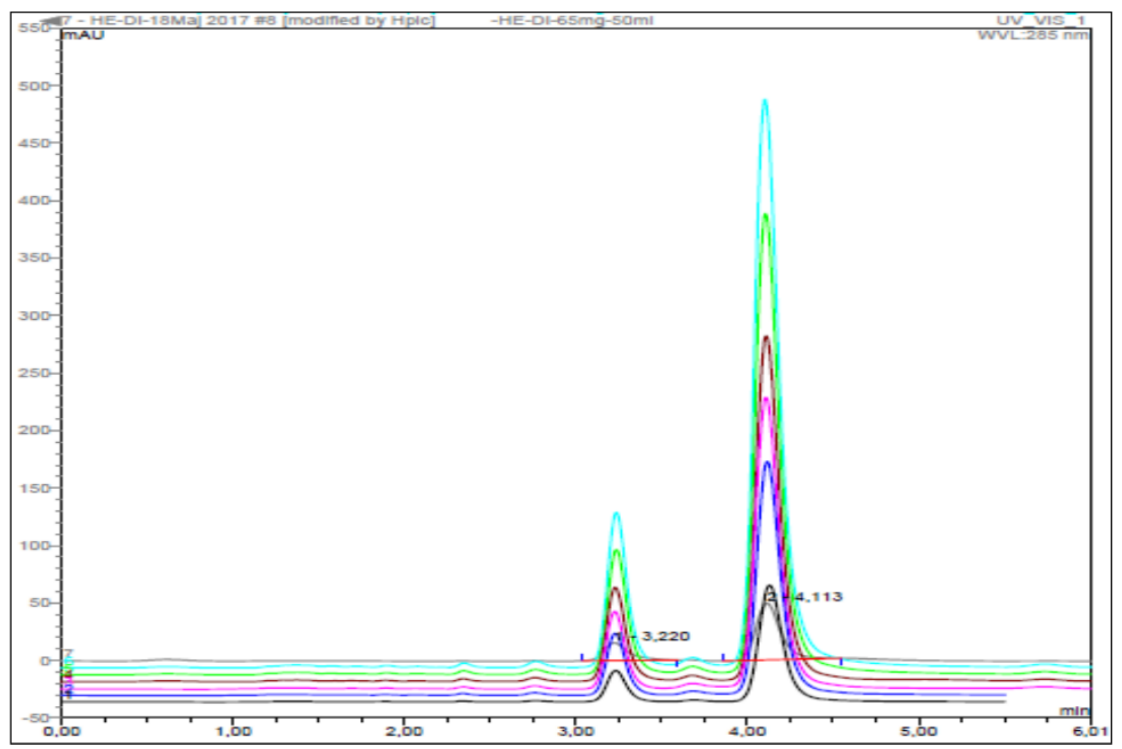

Fig. 5. Chromatograms obtained using UPLC Dionex and column Discovery C18 $100 \mathrm{~mm} \times 4.6 \mathrm{~mm}, 5 \mu \mathrm{m}$, with $40 \%$ methanol in the mobile phase composition

\subsection{Selectivity}

The method was validated according to the ICH guideline for the Validation of analytical procedures Q2(R1) [21].

The method validation was performed on a Varian HPLC system. The following validation parameters were tested: selectivity, linearity, accuracy and precision, from the aspect of system and method repeatability.
The selectivity of the method was determined with evaluation of the obtained chromatograms of the blank ( $0.1 \mathrm{M}$ sodium hydroxide solution), placebo solution, test solution and standard solution.

The chromatograms showed that there is no interference between the principal peaks of diosmin and hesperidin with the components of placebo and the used solvent, and also good resolution of more than 4.5 , between the two principal peaks was achieved (Fig. 6). 


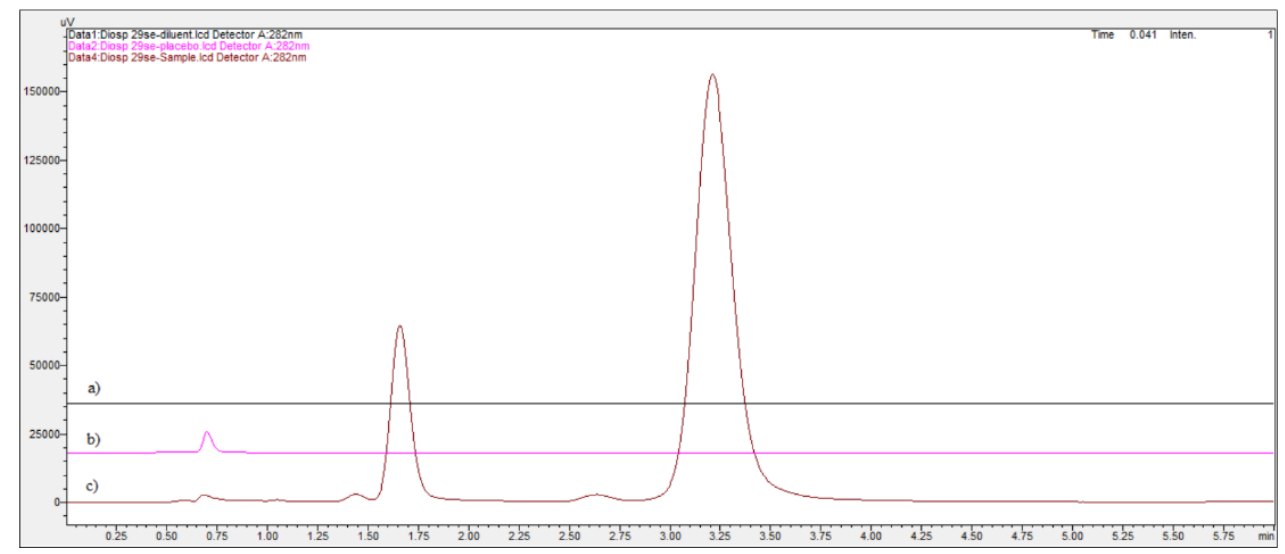

Fig. 6. Overlay of chromatograms representing the selectivity of the method:

a) diluent, b) placebo solution and c) sample solution

\subsection{Linearity}

Linearity was examined and proven at five different concentration levels in the range of 50 $150 \%$ of the final, working concentration of dios$\min (0.18-0.54 \mathrm{mg}$ diosmin $/ \mathrm{ml})$ and hesperidin (0.02-0.06 mg hesperidin $/ \mathrm{ml}$ ).

For diosmin, the relative standard deviation (RSD) of the response factors obtained in each concentration level is $1.84 \%$ with linearity regression equation $y=3297.909 x+9.080$ and an obtained correlation coefficient of $\mathrm{R}^{2}=0.9980$.

The $y$ intercept $\%$ ( $y$ value for $100 \%$ concentration) was calculated as an additional statistical evaluation of the linearity of the prescribed HPLC method. The obtained value of the $y$ intercept is $0.759 \%$.

For hesperidin, the RSD of the response factors obtained in each concentration level is $1.48 \%$ with linearity regression equation $y=5456.034 x+$
2.452 and an obtained correlation coefficient of $\mathrm{R}^{2}$ $=0.9980$. $1.111 \%$.

The obtained value of the $y$ intercept is

\subsection{Accuracy}

The accuracy of the method was tested through the study of analytical recovery, separately determined at three concentration levels of diosmin and hesperidin, with repeatability of three injections at each concentration level.

The developed analytical method was applied to synthetic mixtures of the drug product components with a known added amount of the active substances, corresponding to suitable concentration levels of $\sim 70 \%, 100 \%$ and $130 \%$ of the final, working concentration of diosmin and hesperidin.

Table 1 shows the accuracy of the method for determination of diosmin and hesperidin from the aspect of analytical recovery.

Table 1

Analytical recovery of diosmin and hesperidin

\begin{tabular}{ccc}
\hline \hline $\begin{array}{c}\text { Approximate } \\
\text { concentration level of di- } \\
\text { osmin and hesperidin (\%) }\end{array}$ & Recovery of diosmin (\%) & Recovery of hesperidin (\%) \\
\hline \multirow{2}{*}{70} & 101.92 & 101.69 \\
& 100.14 & 101.24 \\
101.93 & 101.62 \\
\hline \multirow{2}{*}{100} & 98.23 & 100.42 \\
& 101.89 & 101.89 \\
130 & 101.60 & 101.97 \\
\hline \multirow{2}{*}{101.16} & 101.83 \\
& 101.36 & 101.70 \\
& 100.81 & 100.85 \\
\hline & Average recovery $=101.00 \%$ & Average recovery $=101.47 \%$ \\
RSD $=1.18 \%$ & RSD $=0.52 \%$ \\
Correlation coefficient $\left(\mathrm{R}^{2}\right)=0.9983$ & Correlation coefficient $\left(\mathrm{R}^{2}\right)=0.9996$ \\
Slope $=1.0089$ & Slope $=1.0141$ \\
\hline \hline
\end{tabular}


With the obtained percentage of the analytical recovery of diosmin and hesperidin in the range of $100 \pm 2 \%$, RSD $<2 \%$, and correlation coefficient $\left(\mathrm{R}^{2}\right)$ and slope close to 1 , the accuracy of the method is proven (Table 1).

\subsection{Precision}

The precision of the developed method was proven through the testing of system and method repeatability.

The system repeatability was demonstrated using statistical evaluation of the obtained peak areas of diosmin and hesperidin of six subsequent injections of the combined standard solution containing both, diosmin and hesperidin, with final, working concentrations of $\sim 0.36 \mathrm{mg} / \mathrm{ml}$ and $\sim 0.04$ $\mathrm{mg} / \mathrm{ml}$, respectively.

The RSD of the obtained peak areas was very low, i.e. $0.42 \%$ for diosmin and $1.22 \%$ for hesperidin.

In order to determine the method repeatability, the assay test was performed six times, with multiple sampling of the same homogeneous sample under the prescribed conditions.

The obtained results for diosmin and hesperidin content are presented in Table 2.

Table 2

\section{Results of method repeatability testing}

\begin{tabular}{cc}
\hline \hline $\begin{array}{c}\text { Diosmin content } \\
\text { in of the declared } \\
\text { content of 450 mg }\end{array}$ & $\begin{array}{c}\text { Hesperidin content } \\
\text { in \% of the declared } \\
\text { content of 50 mg }\end{array}$ \\
\hline 102.28 & 95.76 \\
101.29 & 97.84 \\
100.22 & 97.04 \\
102.24 & 95.98 \\
101.42 & 97.30 \\
101.33 & 96.26 \\
\hline Average $=101.30 \%$ & Average $=96.70 \%$ \\
SD $=0.72$ & SD $=0.82$ \\
RSD $(\%)=0.71$ & RSD $(\%)=0.85$ \\
\hline \hline
\end{tabular}

The RSD of the obtained results of six subsequent determinations of assay of diosmin and hesperidin is very low in both cases.

\section{CONCLUSIONS}

The presented method for the simultaneous quantification of diosmin and hesperidin from solid dosage formulations offers simplicity essential for quality control of a large number of samples in short time intervals, which is necessary for routine analysis. The concept of mobile phase composition was evaluated and confirmed on different chromatographic systems and columns, with different performances. The octylsilane (i.e. C8) columns proved to be more applicable due to shorter run time of analyses.

Furthermore, the developed method showed good results for the tested validation parameters, i.e. it is selective, accurate, linear and precise, and is thus suitable to be used for the simultaneous quantification of diosmin and hesperidin in combined tablet dosage forms.

Acknowledgements. This research did not receive any specific grant from funding agencies in the public, commercial, or not-for-profit sectors.

\section{REFERENCES}

[1] Diosmin, monograph, Alternative Medicine Review, 9 (3), 308-311 (2004).

[2] V. Kuntić, J. Brborić, I. Antunović-Holclajtner, S. Uskoković-Marković, Evaluating the bioactive effects of flavonoid hespeidin - A new literature data survey, Vojnosanitetski pregled, 71 (1), 60-65 (2014). DOI: 10.2298/VSP1401060K.

[3] P. Gloviczki (ed.), ass. eds. C. M. Dalsing, B. Eklof, L. G. Moneta, W. T. Wakefield, Handbook of Venous Disorders, $3^{\text {rd }}$ ed., Guidelines of the American Venous Forum, CRC Press, Taylor \& Francis Group, LLC, 2008.

[4] D. Srilatha, M. Nasare, B. Nagasandhya, V. Prasad, P. Diwan, Development and validation of UV spectrophotometric method for simultaneous estimation of hesperidin and diosmin in the pharmaceutical dosage form, International Scholarly Research Notices (ISRN) Spectroscopy 2013, 4 pages. DOI: 10.1155/2013/534830.

[5] Z. Moldovan, A. A. Bunaciu, A. M. Al-Omar, Y. H. Aboul-Enein, A spectrophotometric method for diosmin determination, The Open Chemical and Biomedical Methods Journal, 3, 123-127 (2010).

[6] M. Dalia, M. T. Shereen, Fluorimetric determination of diosmin and hesperidin in combined dosage forms and in plasma through complex formation with terbium, Bulletin of Faculty of Pharmacy, Cairo University, 51 (1), 81-88 (2013). DOI: 10.1016/j.bfopcu.2012.12.001.

[7] M. A. El-Shafae, M. M. El-Domiaty, Improved LC methods for the determination of diosmin and/or hesperidin in plant extracts and pharmaceutical formulations, Journal of Pharmaceutical and Biomedical Analysis, 26, 539-545 (2001).

[8] I. F. Kanaze, C. Gabrieli, E. Kokkalou, M. Georgarakis, I. Niopas, Simultaneous reversed-phase highperformance liquid chromatographic method for the determination of diosmin, hesperidin and naringin in different citrus fruit juices and pharmaceutical formulations, Journal of Pharmaceutical and Biomedical Analysis, 33 (2), 243-249 (2003). 
[9] European Pharmacopoeia, 5th ed. European Directorate for the Quality of Medicines - Council of Europe: Strasbourg, 2004.

[10] D. Šatinský, K. Jägerová, L. Havliková, P. Solich, A new and fast HPLC method for determination of rutin, troxerutin, diosmin and hesperidin in food supplements using fused-core column technology, Food Analytical Methods, 6 (5), 1353-1360 (2013). DOI: $10.1007 / \mathrm{s} 12161-012-9551-\mathrm{y}$.

[11] G. Mishra, K. V. Srivastava, A. Tripathi, Analytical method development and validation for assay of diosmin and hesperidin in combined dosage form by RP-HPLC, International Journal of Pharmacy \& Life Sciences, 4 (7), 2834-2839 (2013).

[12] M. K. Anwer, S. Jamil, M. J. Ansari, R. Al-Shdefat, M. S. Abdel-Kader, A new improved stability-indicating RP-HPLC method for determination of diosmin and hesperidin in combination, International Research Journal of Biological Sciences, 3 (6), 41-46 (2014).

[13] B. Patel, K. Mittal, D. Damor, R. Mashru, Quality by design approach to analytical method development for simultaneous estimation of hesperidin methyl chalcone, hesperidin and ascorbic acid in their combined dosage form by RPHPLC method, International Journal of Pharmacy \& Pharmaceutical Research, 4 (2), 44-62 (2015).

[14] F. Ibrahim, S. K. M. El-Din, N. R. El-Shaheny, K. A. ElDeen, K. Shimizu, Simultaneous determination of four vasoactive phytochemicals in different pharmaceutical preparations by a simple HPLC-DAD method, Analytical Methods, 8, 1858-1866 (2016). DOI: 10.1039/C5AY03003J.

[15] M. Szymański, D. Mlynarek, A. Szymański, I. Matlawska, Simultaneous determination of diosmin and hesper- idin in pharmaceuticals by RPLC using ionic liquids as mobile phase modifiers, Iranian Journal of Pharmaceutical Research, 15 (1), 141-148 (2016).

[16] V. Kuntić, N. Pejić, B. Ivković, Z. Vujić, K. Ilić, S. Mićić, V. Vukojević, Isocratic RP-HPLC method for rutin determination in solid oral dosage forms, Journal of Pharmaceutical and Biomedical Analysis, 43 (2), 718721 (2007).

[17] M. Biesaga, U. Ochnik, K. Pyrzynska, Fast analysis of prominent flavonoids in tomato using a monolithic column and isocratic HPLC, Journal of Separation Science, 32 (15-16), 2835-2840 (2009).

[18] M. F. Yam, E. A. Mohamed, L. F. Ang, L. Pei, Y. Darwis, R. Mahmud, M. Z. Asmawi, R. Basir, M. Ahmad, A simple isocratic HPLC method for the simultaneous determination of sinensetin, eupatorin, and 3'-hydroxy-5, 6,7, 4'-tetramethoxyflavone in Orthosiphon stamineus extracts, Journal of Acupuncture and Meridian Studies, 5 (4), 176-182 (2012).

[19] M. N. Islam, H. J. Chung, D. H Kim, H. H. Yoo, A simple isocratic HPLC method for the simultaneous determination of bioactive components of Scutellariae radix extract, Natural Product Research, 26 (21), 1957-1962 (2012).

[20] J. Dolan, A Guide to HPLC and LC-MS Buffer Selection, ACE HPLC Columns, Advanced Chromatography Technologies, Aberdeen, Scotland. Available from: www.acehplc.com [accessed 02.12.2016].

[21] International Conference on Harmonization (ICH) of technical requirements for registration of pharmaceuticals for human use, Validation of Analytical Procedures: Text and Methodology Q2(RI), ICH, Geneva, Switzerland, 2005. 